\title{
Social Acceptance of HIV Positive Child
}

\author{
Sarojini', Dhanraj Ganapathy ${ }^{2}$ and Subhabrata Maiti ${ }^{3}$ \\ ${ }^{1}$ Graduate Student Department of Prosthodontics Saveetha Dental College, Saveetha \\ Institute of Medical and Technical Sciences, Saveetha University, Chennai, India \\ ${ }^{2}$ Professor and Head Department of Prosthodontics, Saveetha Dental College, Saveetha \\ Institute of Medical and Technical Sciences Saveetha University, Chennai, India \\ ${ }^{3}$ Senior Lecturer, Department of Prosthodontics Saveetha Dental College, Saveetha \\ Institute of Medical and Technical Sciences, Saveetha University, Chennai, India
}

\section{ABSTRACT}

The Human immunodeficiency virus (HIV) is a causative agent of acquired immunodeficiency syndrome is an important public health threat worldwide. India is the second-largest country containing a larger number of people affected by AIDS. HIV related stigma and discrimination is present in a tremendous amount in society. Since the first cases of the human immunodeficiency virus (HIV) infection were identified, the number of children infected with HIV has also risen dramatically in developing countries as a result of an increased number of HIV-infected women of childbearing age. This survey was conducted to assess the acceptance of HIV positive children in society. A questionnaire-based online survey was conducted among the general population in South India. A total of 100 participants with an age of 20 or above took part in the survey. Participants in this survey are voluntary and no incentives or motivation were given to the participation. They were also instructed about the questionnaire before the administration of the survey. The survey questionnaire covered all the aspects of pediatric HIV and stigma in our society. All the data from the survey responses were collected and were subjected to statistical analysis. A total of 100 individuals participated in the survey. The participant's ages range from 20 to 60 years of age. The majority of the participants (75\%) were females. Thirtythree percent of our participants denied treating a Pediatric HIV child as a normal child. Twenty-four percent blamed HIV infected children for their illness. Sixty-two percent showed their reluctance to allow their children to play with HIV-infected persons. Even Though 80\% agree to help those children in some way. Among the participants, 22\% feel that persons infected with HIV should feel ashamed of themselves. Nearly 86\% of people expressed their view that HIV infected children should undergo proper treatment and care. A great number of people (78.8\%) wish that they should be treated in a good way in society. This study concluded that children affected by HIV should be treated in a good way in society. The society must be able to accept the affected children and there should be a proper awareness of pediatric HIV. It is important that the children should not be blamed or feel ashamed for their illness. Parents and caregivers should take responsibility and provide care.

KEY WORDS: CHILDREN, HIV, INFECTION, SOCIAL ACCEPTANCE.

\section{ARTICLE INFORMATION}

${ }^{*}$ Corresponding Author: drsubhoprostho@gmail.com

Received 21st July 2020 Accepted after revision 24th Sep 2020

Print ISSN: 0974-6455 Online ISSN: 2321-4007 CODEN: BBRCBA

Thomson Reuters ISI Web of Science Clarivate Analytics USA and Crossref Indexed Journal

$$
\begin{aligned}
& \text { Clarivate } \\
& \text { Analytics }
\end{aligned}
$$

NAAS Journal Score 2020 (4.31) SJIF: 2020 (7.728)

A Society of Science and Nature Publication,

Bhopal India 2020. All rights reserved.

Online Contents Available at: http//www.bbrc.in/

Doi: http://dx.doi.org/10.21786/bbrc/13.8/193 


\section{INTRODUCTION}

The Human immunodeficiency virus (HIV) is a causative agent of acquired immunodeficiency syndrome is an important public health threat worldwide (Weiss, 1993) . HIV infection in India was identified in 1986 and it was estimated that there are more than 5.134 million people infected with HIV infections by the year 2006 (Solomon, Solomon and Ganesh, 2006). India is the second-largest country containing a larger number of people affected by AIDS. HIV related stigma and discrimination is present in a tremendous amount in society (Reyes-Estrada, VarasDíaz and Martínez-Sarson, 2015). Since the first cases of the human immunodeficiency virus (HIV) infection were identified, the number of children infected with HIV has also risen dramatically in developing countries as a result of an increased number of HIV-infected women of childbearing age (Creek et al., 2009). Most of the affected children acquire HIV from mother-to-child HIV transmission that happened during birth, pregnancy or breastfeeding (John-Stewart et al., 2018).
Globally, it was estimated that in the year 2008, there were about 2.1 million children below 15 years affected by HIV. It was estimated that India has an overall prevalence of $0.31 \%$ (Belman, 1992). By the year 2013 around 3.2 million children were living with HIV infections all over the world (Bain, Nkoke and Noubiap, 2017). Children account for 7\% of all the new HIV infections (Mehta et al., 2016) . Maternal to child transmission is the most common cause (more than 90\%) of pediatric HIV (Organization and Others, 2009). A major factor that distinguishes HIV/AIDS from a chronic or terminal illness is the stigma. Too often many HIV infected children and their families have a "conspiracy of silence" and shame associated with AIDS (Faithfull, 1997) . Despite significant advances in HIV treatment and care, children continue to be born with HIV infection mostly due to parent to child transmission. Various factors influence the control of pediatric HIV includes low health service utilization, poor drug adherence, delayed infant diagnosis, a discriminatory attitude of health providers, and loss to follow-up and poor coordination in managing continuum of care (Ghadrshenas et al., 2013).

\begin{tabular}{|c|c|c|}
\hline Questions & $\begin{array}{l}\text { Responses } \\
\text { were given }\end{array}$ & Percentage \\
\hline Are you aware of the term HIV & $\begin{array}{l}\text { Yes } \\
\text { No }\end{array}$ & $\begin{array}{c}96.2 \% \\
3.8 \%\end{array}$ \\
\hline Is HIV a viral infection & $\begin{array}{l}\text { Yes } \\
\text { No }\end{array}$ & $\begin{array}{l}88.5 \% \\
11.5 \%\end{array}$ \\
\hline $\begin{array}{l}\text { Are you aware of the term } \\
\text { pediatric HIV }\end{array}$ & $\begin{array}{l}\text { Yes } \\
\text { No }\end{array}$ & $\begin{array}{l}61.5 \% \\
38.5 \%\end{array}$ \\
\hline $\begin{array}{l}\text { Do you know any child with } \\
\text { pediatric HIV }\end{array}$ & $\begin{array}{l}\text { Yes } \\
\text { No }\end{array}$ & $\begin{array}{l}30.8 \% \\
69.2 \%\end{array}$ \\
\hline $\begin{array}{l}\text { Do you treat HIV positive child as } \\
\text { a normal child }\end{array}$ & $\begin{array}{l}\text { Yes } \\
\text { No }\end{array}$ & $\begin{array}{l}67.3 \% \\
32.7 \%\end{array}$ \\
\hline $\begin{array}{l}\text { HIV infected child should be blamed } \\
\text { for their illness }\end{array}$ & $\begin{array}{l}\text { Yes } \\
\text { No }\end{array}$ & $\begin{array}{l}24 \% \\
76 \%\end{array}$ \\
\hline $\begin{array}{l}\text { Will you allow your child to play } \\
\text { with an HIV infected child }\end{array}$ & $\begin{array}{l}\text { Yes } \\
\text { No }\end{array}$ & $\begin{array}{l}62.5 \% \\
37.5 \%\end{array}$ \\
\hline $\begin{array}{l}\text { Would you like to help an HIV } \\
\text { positive child }\end{array}$ & $\begin{array}{l}\text { Yes } \\
\text { No }\end{array}$ & $\begin{array}{l}79.8 \% \\
20.2 \%\end{array}$ \\
\hline $\begin{array}{l}\text { If you get to know that your close } \\
\text { friend child is infected with HIV will } \\
\text { you keep the same relationship } \\
\text { with him/her }\end{array}$ & $\begin{array}{l}\text { Yes } \\
\text { No }\end{array}$ & $\begin{array}{l}71.2 \% \\
28.8 \%\end{array}$ \\
\hline $\begin{array}{l}\text { Should HIV infected persons } \\
\text { feel ashamed }\end{array}$ & $\begin{array}{l}\text { Yes } \\
\text { No }\end{array}$ & $\begin{array}{l}21.2 \% \\
78.8 \%\end{array}$ \\
\hline $\begin{array}{l}\text { Should HIV infected child get } \\
\text { treated by doctors }\end{array}$ & $\begin{array}{l}\text { Yes } \\
\text { No }\end{array}$ & $\begin{array}{l}85.6 \% \\
14.4 \%\end{array}$ \\
\hline $\begin{array}{l}\text { Should HIV infected child be } \\
\text { treated a good way in society }\end{array}$ & $\begin{array}{l}\text { Yes } \\
\text { No }\end{array}$ & $\begin{array}{l}78.8 \% \\
21.2 \%\end{array}$ \\
\hline $\begin{array}{l}\text { Will you allow an HIV positive child } \\
\text { to study in your child school }\end{array}$ & $\begin{array}{l}\text { Yes } \\
\text { No }\end{array}$ & $\begin{array}{l}72.1 \% \\
27.9 \%\end{array}$ \\
\hline $\begin{array}{l}\text { Would you like to talk or play with } \\
\text { HIV positive child }\end{array}$ & $\begin{array}{l}\text { Yes } \\
\text { No }\end{array}$ & $\begin{array}{l}76.9 \% \\
23.1 \%\end{array}$ \\
\hline
\end{tabular}


Strengthening the existing health system and effective strategies would bring a significant reduction in the incidence of pediatric HIV (Towle, 2009). The chronic medical conditions in the pediatric population pose a range of potential psychosocial challenges not only to the child but also to the family members and health care providers. Previously our department has published extensive research on various aspects of prosthetic dentistry (Ashok et al., 2014; Venugopalan et al., 2014; Ashok and Suvitha, 2016; Ganapathy et al., 2016; Selvan and Ganapathy, 2016; Subasree, Murthykumar and Others, 2016; Vijayalakshmi and Ganapathy, 2016; Ajay et al., 2017; Ganapathy, Kannan and Venugopalan, 2017; Jyothi et al., 2017; Ranganathan, Ganapathy and Jain, 2017; Basha, Ganapathy and Venugopalan, 2018; Kannan and Venugopalan, 2018; Duraisamy et al., 2019; Jain, Nallaswamy and Ariga, 2019), this vast research experience has inspired us to research about social acceptance of HIV positive children among the general population. This survey was conducted to assess the acceptance of HIV positive children in society.

\section{MATERIAL AND METHODS}

A questionnaire-based online survey was conducted among the general population in South India. A total of 100 participants with an age of 20 or above took part in the survey. Participants in this survey are voluntary and no incentives or motivation were given to the participation. They were also instructed about the questionnaire before the administration of the survey. The survey questionnaire covered all the aspects of pediatric HIV and stigma in our society. All the data from the survey responses were collected and were subjected to statistical analysis.

Figure 1: Pie chart representing the age of the participants, $29.52 \%$ were in the age group of $18-29,31.43 \%$ were in the age group of $30-45,23.81 \%$ were between $46-60$ age group and $15.24 \%$ are above the age of 60
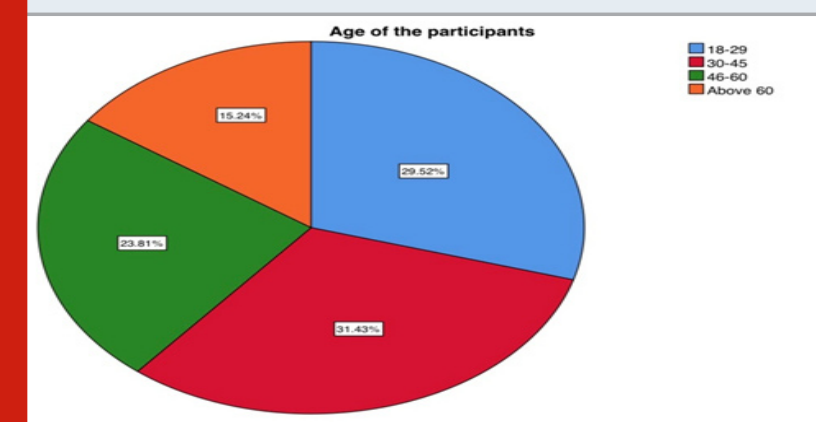

RESULTS AND DISCUSSION

A total of 100 individuals participated in the survey. The participant's ages range from 20 to 60 years of age (Figure 1). The majority of the participants (75\%) were females ( Figure 2). Among the participants, 96.2\% were aware of the term HIV occurring in adults (Figure 3). However, only 61.5\% know about Pediatric HIV (Figure 5). Around 88\% of the participants know that
HIV is a viral infection (Figure 4). When asked about the cause of HIV in children 12.5\% specified mother to child transmission, $14.5 \%$ listed unsterilized syringes, 4.8\% specified transfusion of HIV positive blood and a majority $68.3 \%$ specified all the above-mentioned reasons (Figure 6). Thirty-three percent of our participants denied treating a Pediatric HIV child as a normal child.

Figure 3: Pie chart showing the awareness of HIV occurring in adults, 96.19\% are aware whereas 3.81\% are not aware of it.

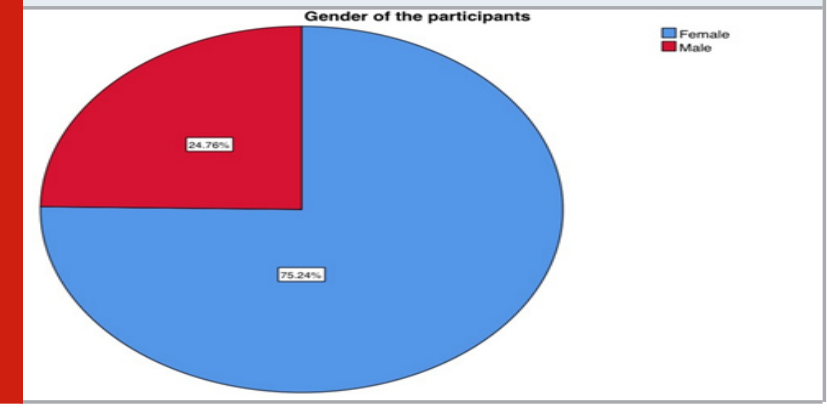

Figure 4: Pie chart showing whether respondents are aware that HIV is a viral disease, $\mathbf{8 8 . 5 7 \%}$ are aware whereas $11.43 \%$ are not aware of it.

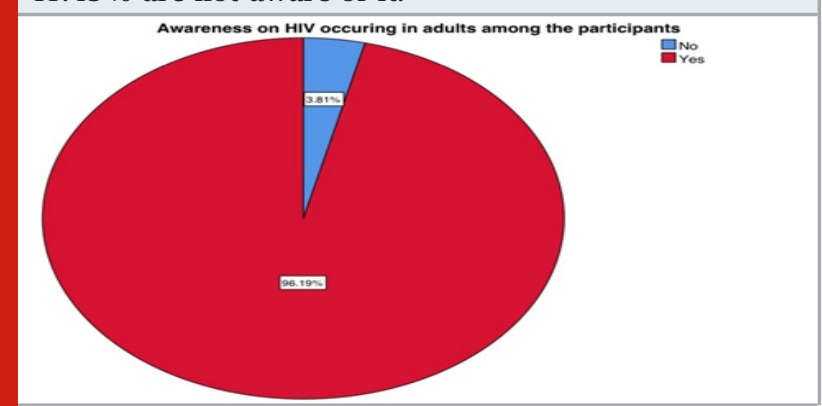

Figure 5: Pie chart representing the awareness of HIV occurring in adults, 61.90 are aware whereas $38.10 \%$ are not aware of it.

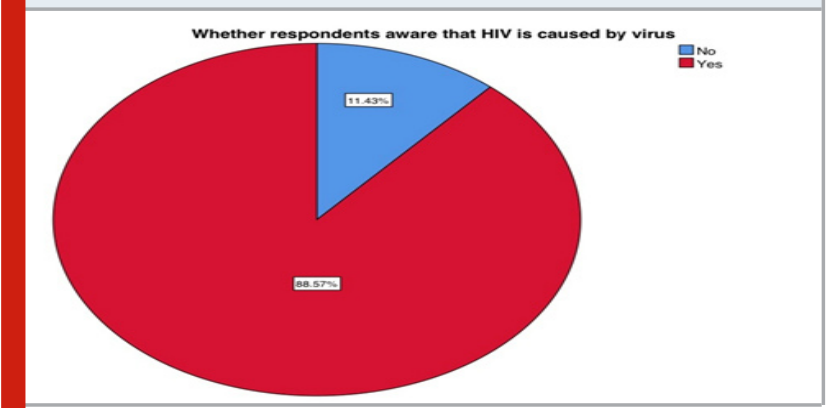

Twenty-four percent blamed HIV infected children for their illness. Sixty-two percent showed their reluctance to allow their children to play with HIV-infected persons. Even Though 80\% agree to help those children in some way (Figure 7). Among the participants, 22\% feel that persons infected with HIV should feel ashamed of themselves. Nearly $86 \%$ of people expressed their view that HIV infected children should undergo proper treatment and care. A great number of people (78.8\%) 
wish that they should be treated in a good way in society (Figure 8). However (27.9\%) do not agree to allow them to study in their child's school. Allover (76.9\%) would like to play and talk with Pediatric HIV children. (Table1)

Figure 6: Pie chart representing the reason for HIV in children responded by our participants, 14.29\% think HIV can be acquired through unsterilized syringes, 13.33\% believe HIV transferred to child from mother during birth, 4.76\% believe through transfusion of HIV positive blood and majority $67.62 \%$ mentioned all the above-mentioned ways.

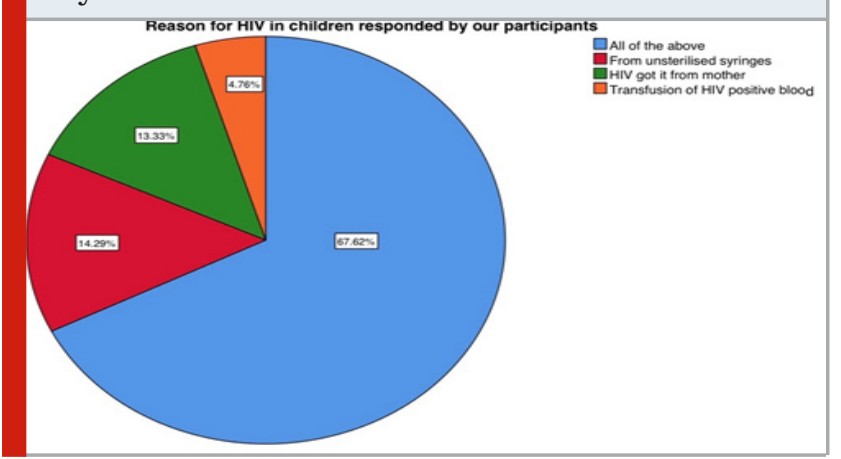

Figure 7: Pie chart showing the responses for whether participants supports HIV positive children, $80 \%$ of the participants help HIV positive children and $20 \%$ of the participants shows a lack of concern.

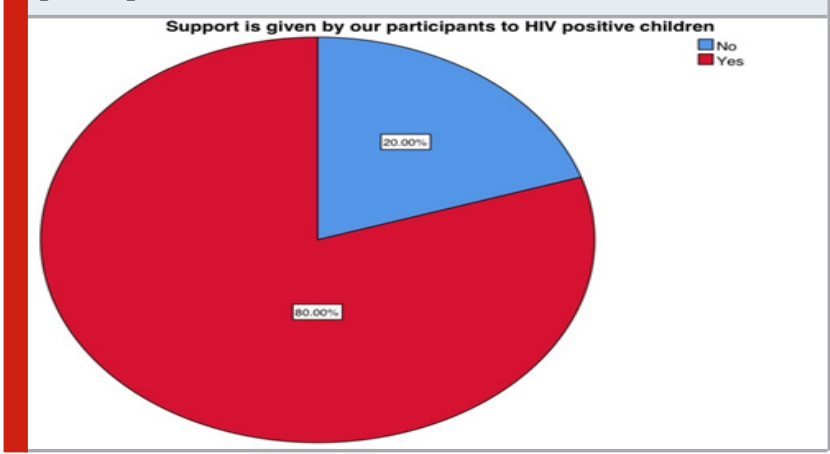

Figure 8: Pie chart showing the acceptance of HIV positive children among the participants, a majority $79.05 \%$ shows the acceptance and the rest $20.95 \%$ are not showing the acceptance.

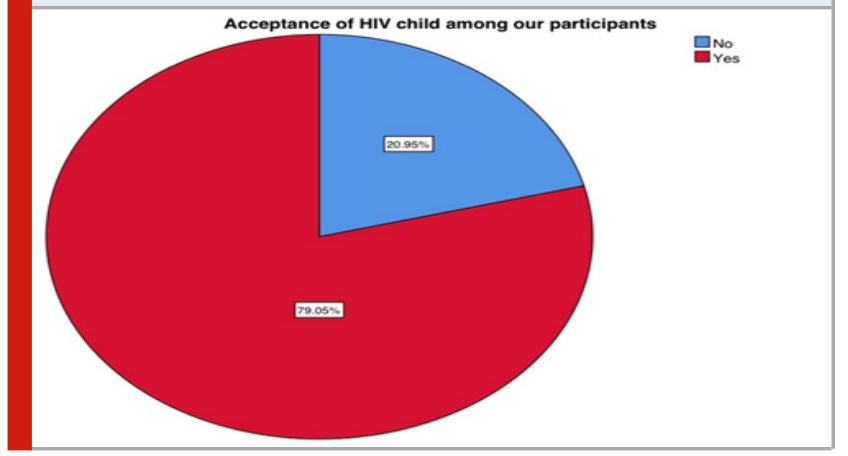

Figure 9: This bar graph represents the association between the age of the participants and awareness of HIV occurring in adults among the participants. $\mathrm{X}$-axis represents the age of the participants and $\mathrm{Y}$-axis represents the number of participants who have awareness of HIV occurring in adults. All of our participants who participated in the age group of 46-60 and the group of people above 60 age showed complete awareness. Whereas $1.90 \%$ are unaware of the age group of 18-29 and 30-45. This was found to be statistically significant. Pearson Chi-square value = 2.671 $\mathrm{a}$ and $\mathrm{P}$-value $=0.045, \mathrm{P}=<0.05$.

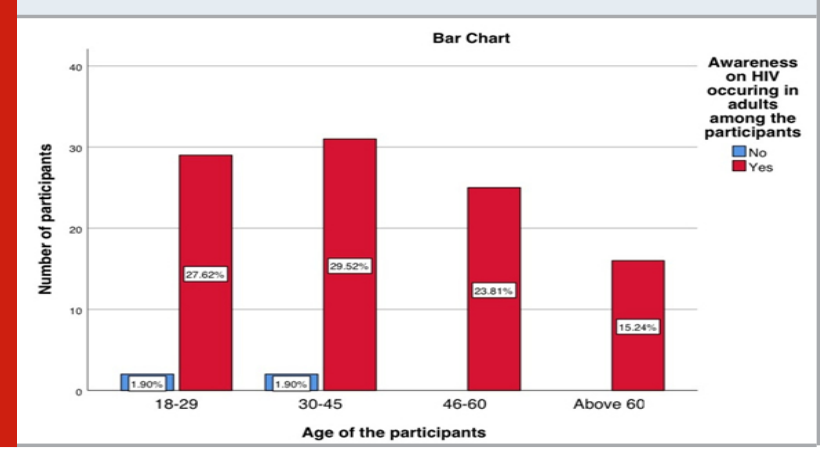

Figure 10: This bar graph represents the association between the age of the participants and awareness of HIV occurring in children (Paediatric HIV) among the participants. $\mathrm{X}$-axis represents the age of the participants and Y-axis represents the number of participants who have awareness of HIV occurring in children. Participants in the age group of 30-45 showed a higher rate of lack of awareness (13.33\%) in comparison with other age groups. This was found to be statistically insignificant. Pearson Chi-square value $=1.469 \mathrm{a}$ and $\mathrm{P}$-value $=0.068$, $P=>0.05$.

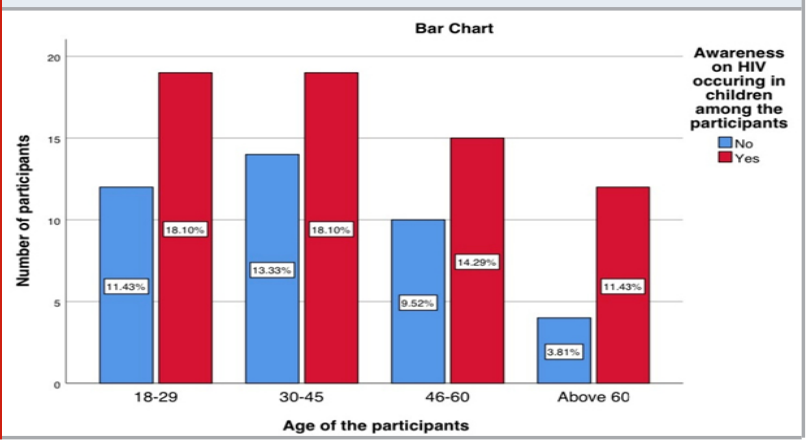

The present study designed to assess the social acceptance of HIV positive children among the general population. In our study, 22\% of the participants feel that persons infected with HIV should feel ashamed. In contrast, a previous study showed half of the participants 50\% agreed that people living with HIV should be ashamed of themselves and were liable for bringing HIV to the community (Dahlui et al., 2015).In our study, 80\% of them expressed their view to help Pediatric HIV children. Similar to a previous study that showed a majority $90 \%$ like to help HIV persons (Jain et al., 2017). Our study results showed that the majority of the participants 
mentioned that the main cause of Pediatric HIV is maternal to child transmission. In comparison, 97\% aware of mother to child transmission is the main cause of HIV in infants in a previous study (Coulibaly et al., 2016).

Figure 11: This bar graph represents the association between the age of the participants and the acceptance of HIV children among our participants. X-axis represents the age of the participants and $\mathrm{Y}$-axis represents the acceptance of HIV children among our participants. Participants in the age group of 30-45 showed a higher rate of lack of acceptance (7.62\%) in comparison with other age groups. Participants in the age group of 1829 showed a higher rate of acceptance $(24.76 \%)$ in comparison with other age groups. This was found to be statistically significant. Pearson Chi-square value $=0.838 \mathrm{a}$ and $\mathrm{P}$-value $=0.048, \mathrm{P}=<0.05$.

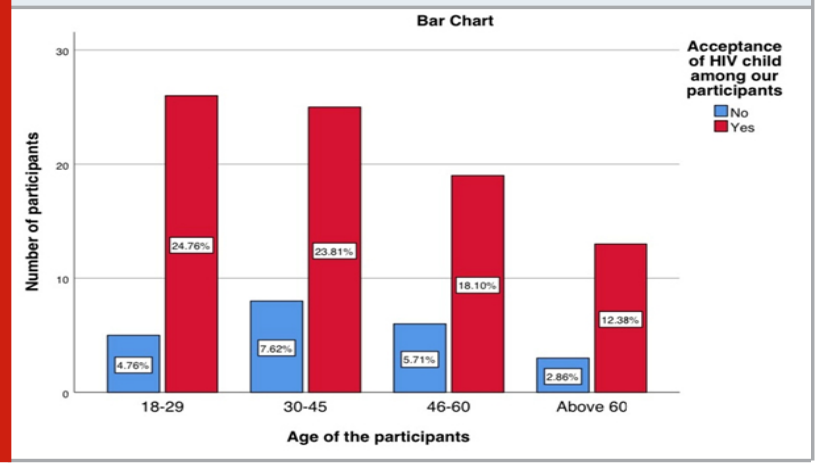

Despite feeling comfortable to help and interact with an HIV-infected person, they still carry the fear of feeling ashamed if they are diagnosed with HIV. Although awareness of pediatric HIV infection among participants is significant, some misconceptions related to the moment of transmission in HIV-exposed children persists. These misconceptions and less awareness about pediatric HIV brings about stigma and less acceptance of HIV infected children in society. Some methodological limitations of this study such as a small sample, the study population may affect the generalizability of the results.

\section{CONCLUSION}

This study concluded that children affected by HIV should be treated in a good way in society. The society must be able to accept the affected children and there should be a proper awareness of pediatric HIV. It is important that the children should not be blamed or feel ashamed for their illness. Parents and caregivers should take responsibility and provide care. They must acknowledge the disease as soon as possible and take measures in saving the child. They must give confidence to their children about their recovery and the society must also not emotionally disturb them. Thus it is important that pediatric HIV children should not be considered separately or to be neglected in the society.

\section{ACKNOWLEDGEMENTS}

The authors are thankful to Saveetha Dental college for providing a platform to express our knowledge.

Conflict of Interest: The authors declare no conflict of interest.

\section{REFERENCES}

Ajay, R. et al. (2017) 'Effect of Surface Modifications on the Retention of Cement-retained Implant Crowns under Fatigue Loads: An In vitro Study', Journal of pharmacy Et bioallied sciences, 9(Suppl 1), pp. S154-S160.

Ashok, V. et al. (2014) 'Lip Bumper Prosthesis for an Acromegaly Patient: A Clinical Report', Journal of Indian Prosthodontic Society, 14(Suppl 1), pp. 279282.

Ashok, V. and Suvitha, S. (2016) 'Awareness of all ceramic restoration in rural population', Research Journal of Pharmacy and Technology, p. 1691. doi: 10.5958/0974-360x.2016.00340.1.

Bain, L. E., Nkoke, C. and Noubiap, J. J. N. (2017) 'UNAIDS 90-90-90 targets to end the AIDS epidemic by 2020 are not realistic: comment on "Can the UNAIDS 90-90-90 target be achieved? A systematic analysis of ...', BMJ global health. gh.bmj.com. Available at: https:// gh.bmj.com/content/2/2/e000227.abstract.

Basha, F. Y. S., Ganapathy, D. and Venugopalan, S. (2018) 'Oral Hygiene Status among Pregnant Women', Research Journal of Pharmacy and Technology. A \& V Publications, 11(7), pp. 3099-3102.

Belman, A. L. (1992) 'Acquired immunodeficiency syndrome and the child's central nervous system', Pediatric clinics of North America. Elsevier, 39(4), pp. 691-714.

Coulibaly, M. et al. (2016) 'Prevention and care of paediatric HIV infection in Ouagadougou, Burkina Faso: knowledge, attitudes and practices of the caregivers', BMC pediatrics. Springer, 16, p. 33.

Creek, T. et al. (2009) 'Factors associated with low early uptake of a national program to prevent mother to child transmission of HIV (PMTCT): results of a survey of mothers and providers, Botswana, 2003', AIDS and behavior. Springer, 13(2), pp. 356-364.

Dahlui, M. et al. (2015) 'HIV/AIDS Related Stigma and Discrimination against PLWHA in Nigerian Population', PloS one. journals.plos.org, 10(12), p. e0143749.

Duraisamy, R. et al. (2019) 'Compatibility of Nonoriginal Abutments With Implants: Evaluation of Microgap at the Implant-Abutment Interface, With Original and Nonoriginal Abutments', Implant dentistry, 28(3), pp. 289-295.

Faithfull, J. (1997) 'HIV-positive and AIDS-infected 
women: Challenges and difficulties of mothering', The American journal of orthopsychiatry. Wiley Online Library, 67(1), pp. 144-151.

Ganapathy, D. et al. (2016) 'Effect of Resin Bonded Luting Agents Influencing Marginal Discrepancy in All Ceramic Complete Veneer Crowns', Journal of clinical and diagnostic research: JCDR, 10(12), pp. ZC67-ZC70.

Ganapathy, D. M., Kannan, A. and Venugopalan, S. (2017) 'Effect of Coated Surfaces influencing Screw Loosening in Implants: A Systematic Review and Metaanalysis', World Journal of Dentistry, pp. 496-502. doi: 10.5005/jp-journals-10015-1493.

Ghadrshenas, A. et al. (2013) 'Improved access to early infant diagnosis is a critical part of a child-centric prevention of mother-to-child transmission agenda', AIDS . journals.lww.com, 27 Suppl 2, pp. S197-205. Jain, A. R., Nallaswamy, D. and Ariga, P. (2019) 'Determination of Correlation of Width of Maxillary Anterior Teeth with Extraoral Factor (Interpupillary Width) in Indian Population', JOURNAL OF CLINICAL AND DIAGNOSTIC RESEARCH. doi: 10.7860/ jcdr/2019/41082.12988.

Jain, M. et al. (2017) 'A questionnaire survey of stigma related to human immunodeficiency virus infection/ acquired immunodeficiency syndrome among healthy population', Community Acquired Infection. Medknow Publications and Media Pvt. Ltd., 4(1), p. 6.

John-Stewart, G. et al. (2018) 'Prevention of Motherto-Child Transmission of HIV and Syphilis', in Holmes, K. K. et al. (eds) Major Infectious Diseases. Washington (DC): The International Bank for Reconstruction and Development / The World Bank.

Jyothi, S. et al. (2017) 'Periodontal health status of three different groups wearing temporary partial denture', Research Journal of Pharmacy and Technology. A \& V Publications, 10(12), pp. 4339-4342.

Kannan, A. and Venugopalan, S. (2018) 'A systematic review on the effect of use of impregnated retraction cords on gingiva', Research Journal of Pharmacy and Technology, p. 2121. doi: 10.5958/0974360x.2018.00393.1.

Mehta, K. G. et al. (2016) 'Drug adherence rate and loss to follow-up among people living with HIV/AIDS attending an ART Centre in a Tertiary Government
Hospital in Western India', Journal of family medicine and primary care. ncbi.nlm.nih.gov, 5(2), pp. 266269.

Organization, W. H. and Others (2009) 'Towards universal access: scaling up priority HIV'. World Health Organization. Available at: https://apps.who.int/iris/ bitstream/handle/10665/44217/9789241598750_eng. pdf.

Ranganathan, H., Ganapathy, D. M. and Jain, A. R. (2017) 'Cervical and Incisal Marginal Discrepancy in Ceramic Laminate Veneering Materials: A SEM Analysis', Contemporary clinical dentistry, 8(2), pp. 272-278.

Reyes-Estrada, M., Varas-Díaz, N. and MartínezSarson, M. T. (2015) 'Religion and HIV/AIDS Stigma: Considerations for the Nursing Profession', The New School psychology bulletin. ncbi.nlm.nih.gov, 12(1), pp. 48-55.

Selvan, S. R. and Ganapathy, D. (2016) 'Efficacy of fifth generation cephalosporins against methicillin-resistant Staphylococcus aureus-A review', Research Journal of Pharmacy and Technology. A \& V Publications, 9(10), pp. 1815-1818.

Solomon, S., Solomon, S. S. and Ganesh, A. K. (2006) 'AIDS in India', Postgraduate medical journal. pmj.bmj. com, 82(971), pp. 545-547.

Subasree, S., Murthykumar, K. and Others (2016) 'Effect of Aloe Vera in Oral Health-A Review', Research Journal of Pharmacy and Technology. A \& V Publications, 9(5), pp. 609-612.

Towle, M. S. (2009) 'Scaling up beyond "pills and skills": preventing parent-to-child HIV/AIDS transmission and the public/private divide in southern India', The International journal of health planning and management. Wiley Online Library, 24(S1), pp. S30-S51.

Venugopalan, S. et al. (2014) 'Case Report: Magnetically retained silicone facial prosthesis', Nigerian journal of clinical practice, 17(2), pp. 260-264.

Vijayalakshmi, B. and Ganapathy, D. (2016) 'Medical management of cellulitis', Research Journal of Pharmacy and Technology. A \& V Publications, 9(11), pp. 2067-2070.

Weiss, R. A. (1993) 'How does HIV cause AIDS?', Science. science.sciencemag.org, 260(5112), pp. 1273-1279. 